\title{
The Coordination of Faculty Services
}

Mr. Abbott is librarian of Trinity University, San Antonio, Texas; $M r$. Kaser is assistant in gifts and exchanges, University of Michigan Library.

$\mathrm{T}$

HERE has beEN considerable discussion recently about providing better library service and facilities to the undergraduate. Many universities are thinking in terms of undergraduate libraries, either of the Lamont type or of the lower divisional variety developed at Iowa. Colleges, too, are developing their own adaptations of these plans. It does not appear, however, that equivalent attention is being given to another major component of academic library clientele: the faculty member.

From the service point of view, the faculty member has been the forgotten man in library thinking for some time. There seems to be an assumption that he is mature, that he has fulfilled his research apprenticeship, and that he ought to know how to get what he wants out of a collection of books. The result is that he has been left largely to his own devices. He has a few troubles, but he usually feels that many of these are the fault of the library. He may be right. The fact is, however, that the average faculty member can get along only "pretty well" in a library. Certainly there must be more effective means for dealing with his needs than those currently in use.

Under the functional system of library organization the two chief service areas are the reference and circulation departments. A large share of the problems of the faculty member, however, are of a different nature from those with which these departments are designed to deal.
The faculty member comes to the library to do research, to see how he can relate class assignments to the library's resources, to plan a new course, to discuss the development of the library's collections in his area of specialty. A half century ago he would probably have taken all these problems to the chief librarian, but today that position is filled by a busy administrator. The instructor is confronted instead with a battery of officers and underlings, each with his own separate area of responsibility. $\mathrm{He}$ is fortunate if he can find a single person who has competence in, interest in, or responsibility for, his field of interest.

Yet why should this situation exist? There are probably more people with advanced subject training working in libraries today then ever before. Many specialists are being assimilated into the library's order, catalog, reference, and circulation departments, or into divisional or departmental libraries, where their subject training is often subordinated, sometimes overwhelmingly, to their other duties. Undoubtedly such specialists could do much more to assist the faculty member if, for purposes of administrative facility, they were not tied to a particular department.

It is the purpose of this paper to suggest that if these specialists could be released from their more general library duties and each given the responsibility of assisting the faculty member in their mutual area of specialization, libraryfaculty relations could be greatly improved. As a staff officer, the province of such a specialist would cut horizontally across all conventional lines of library departmentalization, thus énabling him to give many services "between the 
lines." Depending upon local circumstances, he might deal with only one academic department, or he might be concerned with several related departments. In some instances his function might cut across several departments, but not fully include any of them. In actual practice it might be more suitable to call him the "Historical Studies Librarian," or the "Slavic Studies Librarian," or some other similar term more precisely descriptive of his duties.

In addition to his advanced subject training, this specialist would have an extensive knowledge of the library, its catalogs, its collections, and its peculiarities - those ever-present individualistic elements which only the history of the institution can explain. Besides having a wide familiarity with bibliographical tools, he would know something of the historical development of his subject, be familiar with the book trade, and have a basic knowledge of the principles of bibliographical description. He should have training in foreign languages. He should be acquainted with the existence in other libraries of research collections pertaining to his subject. He should be expected to belong to professional organizations in his special subject area as well as to the appropriate library associations.

In the way of research assistance, he would not only compile bibliographies for faculty members, as is already being done in some academic libraries, but he would also abstract articles and books, arrange for translations of articles written in languages outside the linguistic competence of the instructor, search for, collect, and organize data, carry on correspondence with other research libraries regarding materials; in short, do everything useful to the researcher with the exception of the actual interpretation of the data. Since he would devote much of his time to this type of work, he could presumably do it better, more accurately, efficiently, and rapidly than an in- structor, who, because of his other academic obligations, can devote only a few hours a week to its accomplishment. This principle has long been recognized in legislative reference services at both the federal and state levels.

The obligations of the librarian in this type of work would extend well beyond the research assistance function. Since he would be almost as much a member of the academic department as of the library staff, he might. well be obligated to attend all departmental faculty meetings, acting as a resource person to the faculty in library problems. He might well serve on dissertation committees. In this capacity he would be especially helpful in the beginning stages when the subject of the dissertation is being assessed in terms of the available library resources. It would be his duty to keep informed regarding the assignments being given by instructors. In this way he would be in a position to make suggestions that would keep such assignments realistically related to the resources of the collections. On the other hand, he would be able to see that the library anticipated the demands that would be made upon it. When new courses were being considered, his advice regarding the library's resources in the area would be valuable. He himself would probably be the natural person to teach courses in bibliography and to lecture on library use and facilities.

One of the more important functions of this specialist would be as bibliographer in his subject area, where he would be charged with a major part of the responsibility for the systematic development of the book collections. He would inform faculty of available items likely to be of interest. Faculty requests would go through him for his suggestions, if not approval. He could work closely with the director and the department in locating and assessing special collections that might be purchased or 
obtained for the library as gifts. He would aid in filling in gaps in the collections that might be called to his attention by new instructors. In short, he would keep his bibliographical acumen at all times at the faculty's disposal. Conceivably, over a period of time, as the faculty learned respect for his scholarly integrity, it might choose to relinquish to him the major burden of book selection.

There are, of course, many other ways in which such a person could facilitate the faculty member's work with the library's collections. He could see that a dictating machine is available to the faculty member who chooses to take his notes on tapes or wires or cylinders. The same could be true of typewriters, photocopying devices, or whatever other mechanical conveniences science is making available. He could have student assistants search current periodicals, notifying faculty members when articles appear on subjects in which they have indicated their interests. He could see that local indexes were maintained of subject materials which do not receive that treatment from usual indexing media. He could keep informed as to the location of other research collections; and he should be free to travel to consult such collections when a particular research problem being pursued demands. Experience and imagination would indicate other areas in which such a librarian could render valuable service to the faculty member.

Of course the specialist's services need not be confined to the faculty. Certainly he frequently would be called upon by the library staff itself to assist in solving complex classification problems and in answering reference questions that required special knowledge. If the undergraduate had needs that the reference department was unable to fill, the student could consult the specialist. Graduate students would consult him more often, but since they are expected to perform for themselves certain academic "finger exercises" as part of their educational experience, they would receive more guidance than active assistance. Probably the specialist's services would not be too much in demand by students, however, because their concern with the library is unidimensional; they are interested in it only as a source of information. The faculty member not only shares this concern, but in addition has obligations regarding the selection of books and the coordination of his course work with the resources and services of the library.

In addition to the better service and better book collections that would result from such a program, it would seem reasonable to expect several other fortunate developments. For example, it is probable, that such assistance would further stimulate productive research in the campus community. It should help to minimize further departmentalization of the collections, since in the performance of his duties the specialist would be providing many of the services that the faculty expects to gain under the departmental arrangement. It would help to raise the status of librarians among academic personnel. The creation of such a position would make the profession more attractive to capable persons with strong subject backgrounds. In addition to being an excellent training ground for higher administrative responsibility, it would also be an area in which capable people not interested in administrative work might rise to the top of the profession.

It is not supposed that full acceptance of this service could be established overnight. In some areas there would be skepticism. Advances would have to be made a step at a time; there would have to be adaptations to fit local conditions. For example, the local library would probably find it impracticable to establish immediately a department of sub(Continued on page 40) 
that the Library of Congress printed catalog does not by any manner of means include all the references in the Library of Congress card catalogs, a precedent which might well hold for the published National Union Catalog. And for entries under a variety of forms, the editors must do their best and allowance must be made in the published work for a certain amount of inconsistency. It would be easy to spend millions of dollars in editing the catalog, but this must be avoided. A bird in the hand is worth two in the bush.

The intent of this paper is to urge the acceptance of a limited program for the publication of the National Union Catalog. In essence the publication would be complementary to the Library of Congress printed catalog, as well as to the various other accepted bibliographies. It would not be a complete and perfect bibliography, but it would be a tremendously valuable bibliographical tool, both for the location of copies and for the compilation of bibliographies of various kinds. With the proposed expansion of the Library of Congress $\mathrm{Au}$ thor Catalog into a union catalog, beginning next year, the time has come to reproduce the retrospective National Union Catalog to the best of our ability. If general agreement can be reached on this proposal, we could ask the Library of Congress to study the costs involved, to estimate the size of the subsidy, if any, that would be required, to make possible a publication at a low enough price so that the whole project would become feasible.

\section{Future Program}

\section{(Continued from page 12)}

provide readers with information on developments in the audio-visual field. A number of readers have already expressed favorable comments on this new feature. Librarians in practice can assist in improving the journal by writing and by encouraging their staff members to write. If there is any single criterion to guide writers, it is to present new ideas. Contributors should follow the basic style of the journal in presentation, footnote citations, and tabular organization. We are counting on your full cooperation.-Maurice F. Tauber, Editor.

\section{Faculty Service}

\section{(Continued from page 15)}

ject specialists, but the functions of the specialist might well be performed immediately under the office of the director, or out of a subject divisional library, or out of a departmental library. It is believed, however, that once the service is created the confidence and support necessary to its success would soon be established in sufficient degree to make the innovation successful.

Certainly the librarian convinced of the efficacy of his calling will not cringe at improving or increasing services. Let the faint-hearted but look back over the progress of the last half-century and see how far he has come already. He should note also that special libraries have always given most of the services discussed above. Indeed, the coordination of faculty services entails little more than the adaptation of certain special library practices to an academic situation.

\section{Use of TAAB}

\section{(Continued from page 18)}

which $T A A B$ service provides.

In conclusion, it might be said that the $T A A B$ method has the virtue of being cooperative, comprehensive and competitive. It is cooperative in the sense that libraries and booksellers derive mutual benefit in a new and imaginative way. Comprehensiveness is achieved by the large-scale attention given by booksellers to an individual library's wants. It is competitive because of the number of dealers involved and this tends to encourage low quoting on items desired. The method has much to recommend it. 